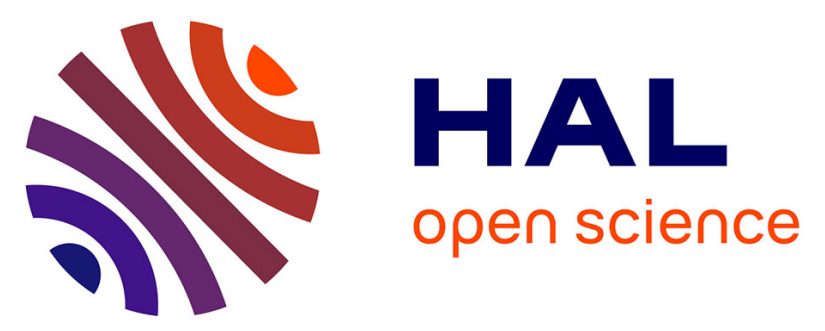

\title{
Monitoring viable airborne inoculum of Botrytis cinerea in the South-East of France over 3 years: relation with climatic parameters and the origin of air masses
}

\author{
Christel Leyronas, Philippe C. Nicot
}

\section{- To cite this version:}

Christel Leyronas, Philippe C. Nicot. Monitoring viable airborne inoculum of Botrytis cinerea in the South-East of France over 3 years: relation with climatic parameters and the origin of air masses. Aerobiologia, 2013, 29 (2), pp.291-299. 10.1007/s10453-012-9280-0 . hal-02646614

\section{HAL Id: hal-02646614 \\ https://hal.inrae.fr/hal-02646614}

Submitted on 29 May 2020

HAL is a multi-disciplinary open access archive for the deposit and dissemination of scientific research documents, whether they are published or not. The documents may come from teaching and research institutions in France or abroad, or from public or private research centers.
L'archive ouverte pluridisciplinaire HAL, est destinée au dépôt et à la diffusion de documents scientifiques de niveau recherche, publiés ou non, émanant des établissements d'enseignement et de recherche français ou étrangers, des laboratoires publics ou privés.

$$
\text { Copyright }
$$


Version définitive du manuscrit publié dans / Final version of the manuscript published in Aerobiologia, 2013, 29, 2, 291-299. The original publication is available at www.springerlink.com :

http://link.springer.com/article/10.1007/s10453-012-9280-0

\title{
Monitoring viable airborne inoculum of Botrytis cinerea in the South-East of France over 3 years: relation with climatic parameters and the origin of air masses.
}

Christel Leyronas*, Philippe C. Nicot

INRA, UR0407 Pathologie Végétale, F-84140 Montfavet, France

*corresponding author, E-mail : christel.leyronas@avignon.inra.fr

Tel: 33(0)4 32722867 Fax: $33(0) 432722842$

\begin{abstract}
Airborne inoculum of Botrytis cinerea was monitored bimonthly during three years (Sept. 2007- Dec. 2010) on a site in the South-East of France located approximately $5 \mathrm{~km}$ away from susceptible crops. Viable inoculum was collected for $96 \%$ of the sampling days, including during cold winter periods and hot and dry summer conditions. The concentration of airborne inoculum was significantly higher during daytime than at night. Peaks of concentration were recorded at different periods each year (Sept-Oct in 2008, May in 2010). The abundance of viable inoculum was positively correlated with average daily relative humidity and negatively correlated with air temperature and solar radiation. The analysis of backward trajectories suggested that air masses originating from the North or the South brought more viable inoculum than those from the West. This study showed that susceptible crops may be at danger from viable inoculum of $B$. cinerea during all seasons of the year, but that risk prediction models could be developed on the basis of climatic conditions and the origin of air masses.
\end{abstract}

Keywords: long distance dispersal, spores, temporal evolution 
Version définitive du manuscrit publié dans / Final version of the manuscript published in Aerobiologia, 2013, 29, 2, 291-299. The original publication is available at www.springerlink.com :

http://link.springer.com/article/10.1007/s10453-012-9280-0

\section{Introduction}

Many fungi are disseminated via the atmosphere from the smallest to the largest geographical scales (up to several thousands of kilometers) in the form of anemophilous spores (Brown and Hovmoller, 2002; Prospero et al., 2005). Some of these fungi are plant pathogens which may cause severe damage to agricultural crops when epidemics are enhanced by rapid dissemination of airborne spores. The key steps in the development of such epidemics (release, dispersal, deposition and germination of spores on the host plant) are affected by meteorological variables (Jones \& Harrison, 2004). Models based on such variables are thus used to forecast the arrival of spores in areas where susceptible crops are grown and estimate the risk of disease development. Examples include models for soybean rust and tobacco blue mold in the USA (Tao et al., 2009; Main et al., 2000; Nesmith, 1984). These predictive tools can help growers rationalize their crop health management practices, particularly chemical control, and thus lead to a reduction in the number of fungicide applications and their environmental impact while maintaining the efficacy of disease control.

Despite its economic importance for many crops, there is no such forecast model to predict the arrival of Botrytis cinerea Pers. Fr. inoculum in French agricultural areas. This airborne fungus is responsible for substantial loss in marketable products and the world market for Botrytis control products was estimated at US\$15-25 million (Elad and Steward, 2004). On its host plants, when conditions are favourable, this fungus may produce several millions of spores in a few days per square centimetre of lesion surface (Nicot et al., 1996) and this may result in rapid epidemic development on the crop (Decognet et al., 2009). Spores are released either by wind gusts or by a twisting motion of conidiophores induced by changes in the relative humidity of the air (Jarvis, 1977). They are predominantly wind dispersed (Jarvis, 1962; Harrison and Lowe, 1987).

Quantitative studies on airborne B. cinerea inoculum have been conducted during the growing season of several major susceptible crops such as grapes in North-West Portugal (Oliveira, 2009) and North-West Spain (Diaz et al., 1997 and 1998; Rodriguez-Rajo et al., 2010; Fernandez-Gonzalez et al., 2011) or strawberry in South-West Spain (Blanco et al., 2006). Spore sampling was realized in the air above or near susceptible crops during the development of grey mould epidemics (Diaz et al., 1997; Blanco et al., 2006; Decognet et al., 2009). Near diseased crops, airborne inoculum followed a diurnal pattern (Blanco et al., 2006; Jarvis, 1962). In multi-year studies, surges of spore concentration are generally not observed at the same period each year (Fernandez-Gonzalez et al., 2011; Oliveira et al., 2009). As the fungus has a wide host range and may also sporulate as a saprophyte on non-living substrates (Holz et al., 2007), the development of a model forecasting surges in inoculum populations would require knowledge on the presence of airborne inoculum throughout the year. Nevertheless, little is known about inoculum abundance outside of the vegetative period of specific crops. 
Version définitive du manuscrit publié dans / Final version of the manuscript published in Aerobiologia, 2013, 29, 2, 291-299. The original publication is available at www.springerlink.com :

http://link.springer.com/article/10.1007/s10453-012-9280-0

Hence, we conducted a study over a three-year period to characterize the temporal evolution of the abundance of $B$. cinerea inoculum on a non cultivated site and to determine if climatic parameters can serve as predictive parameters in a future grey-mould risk forecast model. The specific objectives were to determine (i) if there are differences between daytime and night-time spores concentrations, (ii) if the concentration of airborne spores of B. cinerea follows a seasonal pattern, (iii) if local climatic parameters have a major influence on the quantity of $B$. cinerea spores in the air and (iv) if the origin of air masses has an impact on inoculum abundance.

\section{Materials and methods}

\subsection{Sampling site location}

The air sampling was carried out at a research unit of the French National Institute of Agricultural Research (INRA) in Avignon (lat. 43.95N; long. 4.81E). Avignon is located along the Rhône River in the main fruit and vegetable production area in the South East of France (Figure 1). It is subjected to a Mediterranean climate with hot and dry summers and temperate winters and is predominantly scoured by a strong northern wind (Mistral). This wind is generated by the combined presence of the Azores anticyclone and the depression over the Gulf of Genoa and blows between 5 and 15 days per month (Salameh et al., 2007). Sporadically, intense southern winds loaded with fine particles from the Sahara desert can also blow in the region, mostly from spring to autumn.

All air samples were collected from a single site with the typical configuration of local agricultural landscapes, with windbreak hedges of cypress to the North and the South of the plot. The plot area was covered with wild grasses regularly moved. It was located within an area of horticultural crops. The nearest commercial crops susceptible to $B$. cinerea were located approximately $5 \mathrm{~km}$ from the sampling point.

\subsection{Sampling method}

The quantification of airborne inoculum of $B$. cinerea sampling was carried out twice a month from September 2007 to December 2010, using a high throughput jet sampler (Burkard manufacturing, Rickmansworth, UK) with a flow rate of $500 \mathrm{~L} \mathrm{~min}^{-1}$. The device was located in the middle of the plot and protected from the rain by a shelter allowing necessary air circulation. The sampler orifice was 50 cm above the ground. Airborne inoculum was collected on 9-cm diameter Petri plates filled with the Botrytis spore trap medium (BSTM) described by Edwards and Seddon (2001). This medium is composed of several fungicides and antibiotics (manebe, pentachloronitrobenzene, chloramphenicol and tannic acid) in order to slow down or avoid the growth of bacteria and fast growing fungi. The amount of agar in this medium was increased to 25 g. $\mathrm{L}^{-1}$ in order to limit dehydration. Petri plates containing $20 \mathrm{ml}$ of the Botrytis-selective medium were placed at the base of the sampler's settling 
Version définitive du manuscrit publié dans / Final version of the manuscript published in Aerobiologia, 2013, 29, 2, 291-299. The original publication is available at www.springerlink.com :

http://link.springer.com/article/10.1007/s10453-012-9280-0

chamber. Each sampling date, spores were collected between 8:00 and 17:00 and between 17:00 and 8:00 the following day. In the rest of the article, "day-time sampling" and "night-time sampling" refer to samples taken from 8:00 to 17:00 and from 17:00 to 8:00, respectively. After exposure, all Petri plates were incubated in the laboratory at $20^{\circ} \mathrm{C}$. During a two-week period they were examined daily for fungal development. Every colony showing radially-branched hyphae and producing a dark brown halo in the medium was transferred to Potato Dextrose Agar medium (PDA) for further identification. After 10 days of incubation on PDA, when typical Botrytis sporulation appeared on the plates the number of Botrytis colony-forming units (CFU) was recorded. For practical purposes, we assumed that one colony of Botrytis corresponded to one viable spore collected on the spore trap medium. These counts were then used to estimate the number of viable spores that had been collected in each Petri plate. Since the collection time was different between day and night (9 hours for daytime and 15 hours for night-time), the number of viable spores were reported to the numbers of cubic meters of sampled air, taking into account the sampler's throughput and the sampling duration. Concentrations of viable spores per cubic meter of air were then obtained.

\subsection{Meteorological data acquisition}

Meteorological data (solar radiation, air temperature, wind speed, relative humidity and precipitations) were acquired continuously on a climatic platform (platform CLIMINRA, US1116, AGROCLIM, F-84000 Avignon) located 5 kilometres from the sampling site. These parameters were recorded on a site representative of regional climate.

\subsection{Backward trajectories of air masses}

In order to evaluate the impact of the origin of air masses on the abundance of $B$. cinerea inoculum, backward trajectories of air masses arriving in Avignon on the sampling days were calculated using HYSPLIT (Hybrid Single Particle Lagrangian Integrated Trajectory Model) (Rolph, 2011; Draxler and Rolph, 2011). All trajectories were calculated up to 72 hours before sampling time. Focus was placed on air masses arriving at 1000, 1500 and 2000 meters above ground level.

\subsection{Statistical analysis}

Statistical analyses were performed with StatView (version 5, SAS Institute). Statistical inferences were made at the $5 \%$ level of significance, unless indicated otherwise. Non parametric tests were used to determine correlations (Spearman test) and significant differences (Mann \& Whitney, Kruskal-Wallis) between data. In order to test the significance of the association between airborne spore concentrations and air masses trajectories an exact test of Fisher was realized. 
Version définitive du manuscrit publié dans / Final version of the manuscript published in Aerobiologia, 2013, 29, 2, 291-299. The original publication is available at www.springerlink.com :

http://link.springer.com/article/10.1007/s10453-012-9280-0

\section{Results}

\subsection{Diurnal pattern of B. cinerea airborne inoculum.}

Mean concentrations of $B$. cinerea airborne inoculum recorded during day-time (8:00-17:00) and night (17:00-8:00) were compared. On average for the 84 air sampling days during the three-year period, viable spore concentration was significantly higher during daytime $\left(0.15 \mathrm{sp} . \mathrm{m}^{-3}\right)$ than during the night $\left(0.05\right.$ sp.m $\left.{ }^{-3}\right)\left(\mathrm{P}_{\text {Mann \& Whitney }}<0.0001\right)$ (Figure 2).

\subsection{Seasonal pattern of B. cinerea airborne inoculum.}

For 81 of the 84 sampling days, viable inoculum of $B$. cinerea was detected in the air. Failure to detect viable airborne inoculum occurred only for two sampling dates in June 2008 and one in July 2009 (Figure 3). When airborne inoculum was detected, daily concentrations varied between 0.007 and 0.700 spores per cubic meter of air. Comparison of airborne concentrations among seasons over the whole three-year period (using a Kruskal-Wallis test) showed significant seasonal differences $(\mathrm{P}=0.0022$ ) (Table 1). Generally, inoculum levels of $B$. cinerea tended to be higher during autumn. When data were analysed separately for each individual year, significant differences were observed between seasons for two of the three years. However, the seasonal patterns were different for each year, with highest inoculum concentrations found in autumn for 2008 and in winter for 2010 (Table 1).

\subsection{Relation between B. cinerea airborne inoculum concentrations and climatic parameters.}

Based on Spearman's tests, the abundance of airborne inoculum was negatively correlated with mean and maximum air temperatures and with solar radiation, recorded respectively up to ten and seven days before the sampling date (Table 2). There was a significant positive correlation between inoculum concentration and mean air humidity (from one to ten days before sampling) and minimum humidity (from the sampling date back to 10 days earlier). Abundance of airborne inoculum was positively correlated with mean wind speed and maximum wind speed measured on the sampling date but not on previous days. It wasn’t generally correlated with precipitations.

\subsection{Relation between inoculum and air mass trajectory}

Backward trajectories of air masses present on the sampling site during sampling dates were determined for the ten sampling days with the highest airborne inoculum concentrations (between 0.7 et $0.2 \mathrm{sp} . \mathrm{m}^{-3}$ ) and for the twelve days with the lowest concentrations (from 0 to $0.01 \mathrm{sp} . \mathrm{m}^{-3}$ ). Air masses with the highest concentrations came 5 times from the South (travelling above the Mediterranean Sea), 4 times from the North East (reaching Avignon down the Rhône Valley) and only once from the West (travelling above the Atlantic Ocean and the Central Mountains) (Figure 4). The twelve air masses with the lowest concentrations arrived 7 times from the West, 3 times from the South and twice from the North. Fisher's exact test to evaluate the association between inoculum 
Version définitive du manuscrit publié dans / Final version of the manuscript published in Aerobiologia, 2013, 29, 2, 291-299. The original publication is available at www.springerlink.com :

http://link.springer.com/article/10.1007/s10453-012-9280-0

concentration and the origin of air masses showed $(\mathrm{P}$ value $=0.07)$ that air arriving from the West tended to bring less inoculum to Avignon than air from the North or the South.

\section{Discussion}

The aim of the present work was to determine when and in which quantity viable inoculum of B. cinerea was present in the air above a site and to determine if this presence was linked to climatic parameters or to the origin of air masses. To our knowledge, this three-year study provides the first quantification of viable airborne populations of this fungus for periods extending outside of the growing season of a specific crop. It generated several intriguing results compared to existing knowledge on airborne inoculum of this fungus.

On our sampling site, viable airborne inoculum of $B$. cinerea was detected for all but three of the sampling dates. This quasi-permanent presence of viable airborne inoculum, including in hot and dry summer conditions, was somewhat unexpected as the growth and sporulation of $B$. cinerea is known to be fostered by cool and humid conditions (Jarvis, 1977; O’Neill et al., 1997). In a climate under oceanic influence in the North West of the Iberian Peninsula, the presence of airborne B. cinerea spores in the summer (without information on their viability) was reported on several agricultural sites. One site was in the Amares area of Portugal, near crops known to be susceptible to the pathogen (Oliveira et al., 2009). Another site was in a vineyard in the Ribeiro area of Galicia (Spain) which was affected by grey mould (Rodriguez-Rajo et al., 2010). Spores of the fungus were also found in the summer on urban sites in climates under oceanic (Oliveira et al., 2005) and continental influence (Stepalka and Wolek, 2005).

It also came as a surprise that viable inoculum was detected in all our winter samples, including dates when temperatures were below $0^{\circ} \mathrm{C}$, as $B$. cinerea is not expected to sporulate in such cold conditions, but rather, to overwinter mainly as sclerotia on the ground (Jarvis, 1977). We can hypothesize that spores may have been transported from a distant source located in conditions more conducive to development and sporulation of B. cinerea (South of Spain, North Africa for example). This hypothesis was supported by two of the seven backward trajectories established on winter dates (see for example Figure 4). Another hypothesis is that B. cinerea strains collected in winter may have the ability to develop at low temperature. A few cases of mycelial growth of $B$. cinerea at temperatures as low as $0^{\circ} \mathrm{C}$ and of sporulation at $5^{\circ} \mathrm{C}$ have been reported (Jarvis, 1977).

Another intriguing result of our study is the generally low concentration of airborne inoculum of $B$. cinerea recorded throughout the three-year period in comparison with those reported in previous studies. While the highest inoculum concentration observed in our study was 0.7 spores per cubic meter, reported levels are often in the range of tens or hundreds in non-agricultural settings (Oliveira et al. 2005; Stepalska and Wolek, 2005, Kasprzyk and Worek, 2006) and hundreds or thousands near or 
Version définitive du manuscrit publié dans / Final version of the manuscript published in Aerobiologia, 2013, 29, 2, 291-299. The original publication is available at www.springerlink.com :

http://link.springer.com/article/10.1007/s10453-012-9280-0

above crops affected by B. cinerea (Jarvis, 1962; Diaz et al., 1997 \& 1998; Blanco et al., 2006; Rodriguez-Rajo et al., 2010; Fernandez-Gonzalez et al., 2011). One possible explanation for the low values of our study could stem from the fact that our air sampler was not localized in the vicinity of diseased crops. Several studies have indicated that local airborne dispersion of $B$. cinerea inoculum occurs mostly on a small distance from a source. It was shown for example that $95 \%$ of $B$. cinerea spores were deposited within one meter of their source in a vineyard (Seyb, 2004) and that few spores were detected beyond 2.5 meters of the source in a snap bean field (Johnson and Powelson, 1983). Another possible explanation could be that inoculum levels are intrinsically low in the sampling region of our study. The climate in Avignon is quite dry and sunny, particularly in spring and summer, conditions that are unfavourable both for sporulation by B. cinerea (Jarvis, 1977) and for inoculum survival as dehydration and UV may decrease viability of spores (Rotem and Aust, 1991). A third possible hypothesis could be that viable inoculum generally accounts for a small proportion of total $B$. cinerea airborne inoculum. Quantifying viable inoculum was a necessity in our study, in relation to our long term objective to build a disease prediction system, because models could be inaccurate if a large proportion of spores were dead and thus unable to attack plants (Aylor, 1999). In contrast, previous studies dealing with airborne inoculum of $B$. cinerea have relied mostly on spore counts under the microscope; without distinguishing viable and dead spores (Blanco et al., 2006 ; Oliveira et al., 2005 and 2009; Stepalska and Wolek, 2005; Diaz et al., 1997). The presence of large numbers of dead spores in those counts may not be ruled out, as they may loose viability during transport because of ambient conditions (Rotem and Aust, 1991). It would be useful for future work to assess the proportion of viable spores in air samples, although determining viable spores with a cultivation method as done in the present study is quite a long and labour-intensive process (at least 2 weeks were needed to ensure that collected spores were B. cinerea) compared to direct microscopic quantification of spores or possible assessment via quantitative PCR (Rogers et al., 2009).

The long duration of the present study allowed us to observe annual variability and different seasonal patterns each year. As far as we know, this is the first study where viable airborne inoculum concentration of $B$. cinerea was monitored regularly throughout several years. Monitoring spore concentration between March and October for three years, Oliveira et al. (2009) showed that peaks of spores occurred at different times every year on a rural site surrounded by crops susceptible to $B$. cinerea. A similar phenomenon was found for viable inoculum in our study. As no diseased crops were present in the vicinity of our sampling site, we may wonder about the origin of this inoculum. Three hypotheses may be proposed: (i) Spores of $B$. cinerea may have been produced (undetected) near the sampling site on weeds or plant debris, as this fungus is well known both for its wide host range and for its saprophytic ability (Beever and Weeds, 2004; Holz et al., 2004). This hypothesis is supported by the fact that there were generally more spores in the air during the day than during the 
Version définitive du manuscrit publié dans / Final version of the manuscript published in Aerobiologia, 2013, 29, 2, 291-299. The original publication is available at www.springerlink.com :

http://link.springer.com/article/10.1007/s10453-012-9280-0

night, as such a diurnal pattern was observed in studies with sampling devices located near diseased cultures (Hartill, 1980; Jarvis, 1962; Blanco et al., 2006). Another fact supporting this hypothesis is the significant correlations found between airborne spore concentration and some local climatic parameters (air temperature, relative humidity and wind speed), suggesting a local inoculum source. It has to be noted that these parameters may have an impact on different mechanisms in relation to the presence of spore in the atmosphere. For example, humidity and temperature may rather affect sporulation while wind is known to affect spore release. (ii) The second hypothesis is that the inoculum may have a distant origin. Coupling concentrations of airborne inoculum of $B$. cinerea with backward trajectories of air masses showed that air masses arriving on the sampling site from the West are less likely to bring viable spores of $B$. cinerea than those coming from the North or the South. Thus, there may be a lower risk of grey mould outbreaks in Avignon when air masses come from the West. (iii) Finally, the more likely hypothesis may be that airborne inoculum of $B$. cinerea found on our sampling site is a mix of local and distant origin. This complicates matters to predict the arrival of spores because many local and distant climatic variables must be taken into account. Further work is needed to distinguish inoculum according to its local or distant origin. To address this question, strains collected in the air at several dates will be characterized with molecular tools to evaluate the relationship between the trajectories of air masses and the presence of specific strains of the fungus.

\section{Conclusion}

Viable inoculum of $B$. cinerea was present most of the time in the air of Avignon during the three years of the present survey. The relationship between inoculum concentrations and local climatic parameters and trajectories of air masses suggests that airborne inoculum may have both a local and a distant origin. More work is needed to develop tools able to forecast the arrival of inoculum in this region. Nevertheless, the results obtained by this study can already provide some operational advice for the plant growers in the region of Avignon: (i) Even in the absence of detected diseased plant in the direct vicinity of a site, there is still an epidemiological risk because of the quasi-permanent presence of viable inoculum of $B$. cinerea in the air, (ii) Attention needs to be paid not only to symptoms on surrounding diseased crops but also on debris and neighbouring weeds on which $B$. cinerea may grow and sporulate. (iii) Epidemiological vigilance should be heightened when weather forecasts announce air masses coming from the North or the South. 
Version définitive du manuscrit publié dans / Final version of the manuscript published in Aerobiologia, 2013, 29, 2, 291-299. The original publication is available at www.springerlink.com :

http://link.springer.com/article/10.1007/s10453-012-9280-0

\section{Acknowledgements}

This study was partially supported by a grant of the INRA department of Plant Health and Environment. The authors gratefully acknowledge the National Oceanic and Atmospheric Administration (NOAA) Air Resources Laboratory (ARL) for the provision of the HYSPLIT transport and dispersion model and READY website (http://www.arl.noaa.gov/ready.php) used in this publication.

\section{References}

Aylor D.E. (1999) Biophysical scaling and the passive dispersal of fungus spores: relationship to integrated pest management strategies. Agricultural and Forest Meteorology 97, 275-292

Beever R. and Weeds P. (2004) Taxonomy and genetic variation of Botrytis and Botryotinia. In: Elad Y., Williamson B., Tudzynski P., Delen N. (eds), Botrytis: biology, pathology and control, pp. 29-52. Kluwer Academic Publishers, Dordrecht, The Netherlands

Blanco C., de los Santos B. and Romero F. (2006) Relationship between concentrations of Botrytis cinerea conidia in air, environmental conditions, and the incidence of grey mould in strawberry flowers and fruits. European Journal of Plant Pathology 114, 415-425

Brown J.K.M. and Hovmoller M.S. (2002) Aerial dispersal of pathogens on the global and continental scales and its impact on plant disease. Science 297, 537-541

Decognet V., Bardin M., Trottin-Caudal Y. and Nicot P.C. (2009) Rapid change in the genetic diversity of Botrytis cinerea populations after the introduction of strains in a tomato glasshouse. Phytopathology 99, 185-193

Diaz M.R., Iglesias I. and Jato M.V. (1997) Airborne concentrations of Botrytis, Uncinula and Plasmopara spores in a vineyard in Leiro-Ourense (N.W. Spain). Aerobiologia 13, 31-35

Diaz M.R., Iglesias I. and Jato V. (1998) Seasonal variation of airborne fungal spore concentrations in a vineyard of North-West Spain. Aerobiologia 14, 221-227

Draxler R.R. and Rolph G.D. (2011) HYSPLIT (HYbrid Single-Particle Lagrangian Integrated Trajectory) Model access via NOAA ARL READY Website

(http://ready.arl.noaa.gov/HYSPLIT.php). NOAA Air Resources Laboratory, Silver Spring, MD.

Edwards S.G. and Seddon B. (2001) Selective media for the specific isolation and enumeration of Botrytis cinerea conidia. Letters in Applied Microbiology 32, 63-66

Elad Y. and Steward A. (2004) Microbial control of Botrytis spp. In: Elad Y., Williamson B., Tudzynski P., Delen N. (eds), Botrytis: biology, pathology and control, pp. 223-241. Kluwer Academic Publishers, Dordrecht, The Netherlands. 
Version définitive du manuscrit publié dans / Final version of the manuscript published in Aerobiologia, 2013, 29, 2, 291-299. The original publication is available at www.springerlink.com :

http://link.springer.com/article/10.1007/s10453-012-9280-0

Fernández-González M., Rodríguez-Rajo F. J., Jato V., Escuredo O. and Aira M. J. (2011) Estimation of yield 'Loureira’ variety with an aerobiological and phenological model. Grana 50, 63-72

Harrison J.G. and Lowe R. (1987) Wind dispersal of conidia of Botrytis spp. pathogenic to Vicia faba. Plant Pathology 36, 5-15

Hartill W.F.T. (1980) Aerobiology of Sclerotinia sclerotiorum and Botrytis cinerea spores in New Zealand tobacco crops. New Zealand Journal of Agricultural Research 23, 259-262

Holz G., Coertze S. and Williamson B. (2004) The ecology of Botrytis on plant surfaces. In: Elad Y., Williamson B., Tudzynski P., Delen N. (eds), Botrytis: biology, pathology and control, pp. 9-24. Kluwer Academic Publishers, Dordrecht, The Netherlands

Jarvis W.R. (1962) The dispersal of spores of Botrytis cinerea Fr. in a raspberry plantation. Transactions of the British Mycological Society 45, 549-559

Jarvis W.R. (1977) Botryotinia and Botrytis species: taxonomy, physiology and pathogenicity. Canada Department of Agriculture 195p

Jones A.M. and Harrison R.M. (2004) The effects of meteorological factors on atmospheric bioaerosol concentrations-a review. Science of the Total Environment 326, 151-180

Johnson K.B. and Powelson M.L. (1983) Analysis of spore dispersal gradients of Botrytis cinerea and gray mold disease gradients in snap beans. Phytopathology 73, 741-746

Kasprzyk I. and Worek M. (2006) Airborne fungal spores in urban and rural environments in Poland. Aerobiologia 22, 169-176

Main C.E., Keever Z.T., Melton T.A., Davis J.M., Barnett O.W., Shoemaker P.B., Creswell T., Corl J.D. and Kincy K. (2000) North American Plant Disease Forecast Center homepage: http://www.ces.ncsu.edu/depts/pp/bluemold/

Nesmith W.C. (1984) The North American blue moldwarning system. Plant Disease 68, 933-936

Nicot P.C., Mermier M., Vaissière B.E. and Lagier J. (1996) Differential spore production by Botrytis cinerea on agar medium and plant tissue under near-ultraviolet light-absorbing polyethylene film. Plant Disease 80, 555-558

Oliveira M., Guerner-Moreira J., Mesquita M.M. and Abreu I. (2009) Important phytopathogenic airborne fungal spores in a rural area: incidence of Botrytis cinerea and Oidium spp. AAEM 16, 197-204

Oliveira M., Ribeiro H. and Abreu I. (2005) Annual variation of fungal spores in atmosphere of Porto: 2003. AAEM 12, 309-315

O’Neill T.M., Shtienberg D. and Elad Y. (1997) Effect of some host and microclimate factors on infection of tomato stems by Botrytis cinerea. Plant Disease 81, 36-40. 
Version définitive du manuscrit publié dans / Final version of the manuscript published in Aerobiologia, 2013, 29, 2, 291-299. The original publication is available at www.springerlink.com :

http://link.springer.com/article/10.1007/s10453-012-9280-0

Prospero J. M., Blades E., Mathison G. and Naidu R. (2005) Interhemispheric transport of viable fungi and bacteria from Africa to the Caribbean with soil dust. Aerobiologia 21, 1-19

Rodríguez-Rajo F.J., Jato V., Fernández-González M. and Aira M.J. (2010) The use of aerobiological methods for forecasting Botrytis spore concentrations in a vineyard. Grana 49, 56-65

Rogers S.L., Atkins S. D. and West J. S. (2009) Detection and quantification of airborne inoculum of Sclerotinia sclerotiorum using quantitative PCR. Plant Pathology 58, 324-331

Rolph G.D. (2011) Real-time Environmental Applications and Display sYstem (READY) Website (http://ready.arl.noaa.gov). NOAA Air Resources Laboratory, Silver Spring, MD.

Rotem J. and Aust H.J. (1991) The effect of ultraviolet and solar radiation and temperature on survival of fungal propagules. Journal of Phytopathology 133, 76-84

Salameh T., Drobinski P., Menut L., Bessagnet B., Flamant C., Hodzic A. and Vautard R. (2007) Aerosol distribution over the western Mediterranean basin during a Tramontane/Mistral event. Annales Geophysicae 25, 2271-2291

Seyb A.M. (2004) Botrytis cinerea inoculum sources in the vineyard system. PhD Dissertation, Lincoln University, Lincoln, New Zealand

Stepalka D. and Wolek J. (2005) Variation in fungal spore concentrations of selected taxa associated to weather conditions in Cracow, Poland, in 1997. Aerobiologia 21, 43-52

Tao Z., Malvick D., Claybrooke R., Floyd C., Bernacchi C. J., Spoden G., Kurle J., Gay D., Bowersox V. and Krupa S. (2009) Predicting the risk of soybean rust in Minnesota based on an integrated atmospheric model. International Journal of Biometeorology 53, 509-521 


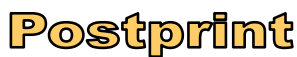

Version définitive du manuscrit publié dans / Final version of the manuscript published in Aerobiologia, 2013, 29, 2, 291-299. The original publication is available at www.springerlink.com :

http://link.springer.com/article/10.1007/s10453-012-9280-0

Table 1: Means of seasonal spore concentrations (spores. $\mathrm{m}^{-3}$ ) and standard error of the mean for the whole period of sampling (total) and for each year.

\begin{tabular}{|c|c|c|c|}
\hline Winter & Spring & Summer & Autumn \\
\hline
\end{tabular}

$\begin{array}{llllll}\text { total } & 0.080 \pm 0.01 & 0.088 \pm 0.03 & 0.043 \pm 0.01 & 0.136 \pm 0.03 & \mathrm{P}=0.0022 \\ 2008 & 0.099 \pm 0.03 & 0.050 \pm 0.01 & 0.059 \pm 0.03 & 0.294 \pm 0.07 & \mathrm{P}=0.0043 \\ 2009 & 0.090 \pm 0.03 & 0.036 \pm 0.02 & 0.020 \pm 0.01 & 0.044 \pm 0.01 & \mathrm{P}=0.0377 \\ 2010 & 0.058 \pm 0.02 & 0.192 \pm 0.08 & 0.058 \pm 0.01 & 0.054 \pm 0.01 & \mathrm{P}=0.1779\end{array}$




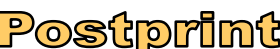

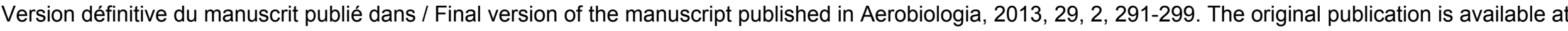
www.springerlink.com : http://link.springer.com/article/10.1007/s10453-012-9280-0

Table 2: Spearman's rank correlation between airborne inoculum concentrations and climatic parameters measured on CLIMINRA platform during the sampling day and several days before.

\begin{tabular}{|c|c|c|c|c|c|c|c|c|c|c|}
\hline & $\begin{array}{c}\text { Solar } \\
\text { radiation }\end{array}$ & Precipitations & $\begin{array}{c}\text { Mean air } \\
\text { temperature }\end{array}$ & $\begin{array}{l}\text { Minimum air } \\
\text { temperature }\end{array}$ & $\begin{array}{l}\text { Maximum air } \\
\text { temperature }\end{array}$ & Mean humidity & $\begin{array}{l}\text { Minimum } \\
\text { humidity }\end{array}$ & $\begin{array}{c}\text { Maximum } \\
\text { humidity }\end{array}$ & $\begin{array}{c}\text { Mean wind } \\
\text { speed }\end{array}$ & $\begin{array}{c}\text { Maximum } \\
\text { wind speed }\end{array}$ \\
\hline$\rho_{D}$ & $-0.315 *$ & $0.1816 \mathrm{NS}$ & $-0.234 *$ & -0.114 NS & $-0.286 * *$ & $0.191 \mathrm{NS}$ & $0.373 * * *$ & $0.092 \mathrm{NS}$ & $0.227 *$ & $0.236^{*}$ \\
\hline$\rho_{\mathrm{D}-2}$ & $-0.353 * * *$ & $0.049 \mathrm{NS}$ & $-0.252 *$ & $-0.203 \mathrm{NS}$ & $-0.269 *$ & $0.298 * *$ & $0.334^{* *}$ & $0.006 \mathrm{NS}$ & $-0.708 \mathrm{NS}$ & $-0.110 \mathrm{NS}$ \\
\hline$\rho_{\mathrm{D}-3}$ & $-0.318 * *$ & -0.032 NS & $-0.319 * *$ & $-0.304 * *$ & $-0.350 * *$ & $0.249 *$ & 0.430 & $0.076 \mathrm{NS}$ & $-0.011 \mathrm{NS}$ & $-0.86 \mathrm{NS}$ \\
\hline$\rho_{\text {D-7 }}$ & $-0.385 * * *$ & $0.260 *$ & $-0.361 * * *$ & $-0.344 * *$ & $-0.333 * *$ & $0.427 * * *$ & $0.372 * * *$ & $0.271^{*}$ & $-0.085 \mathrm{NS}$ & $-0.92 \mathrm{NS}$ \\
\hline$\rho_{\mathrm{D}-10}$ & $-0.204 \mathrm{NS}$ & $0.069 \mathrm{NS}$ & $-0.282 *$ & $-0.260 *$ & $-0.243^{*}$ & $0.224^{*}$ & $0.174 \mathrm{NS}$ & $0.149 \mathrm{NS}$ & $-0.062 \mathrm{NS}$ & $-0.012 \mathrm{NS}$ \\
\hline
\end{tabular}

Significance levels: NS, non significant; * significant at $\mathrm{P}=0.05$; ** significant at $\mathrm{P}=0.01$; *** significant at $\mathrm{P}=0.001$

D , D-1 indicates the day of measurement of climatic parameters : D is the day of sampling, D-1 is the day before sampling etc. 


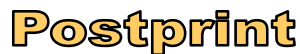

Version définitive du manuscrit publié dans / Final version of the manuscript published in Aerobiologia, 2013, 29, 2, 291-299. The original publication is available at www.springerlink.com :

http://link.springer.com/article/10.1007/s10453-012-9280-0

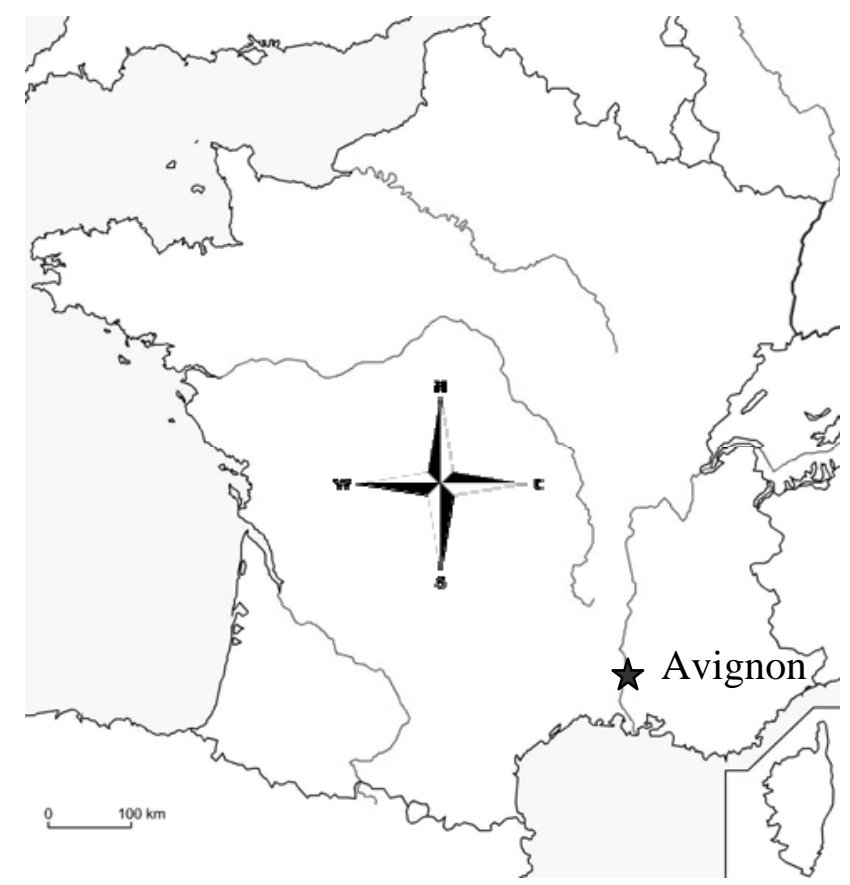

Fig. 1 Geographic location of the sampling site: Avignon is located in the Rhône River valley oriented North to South

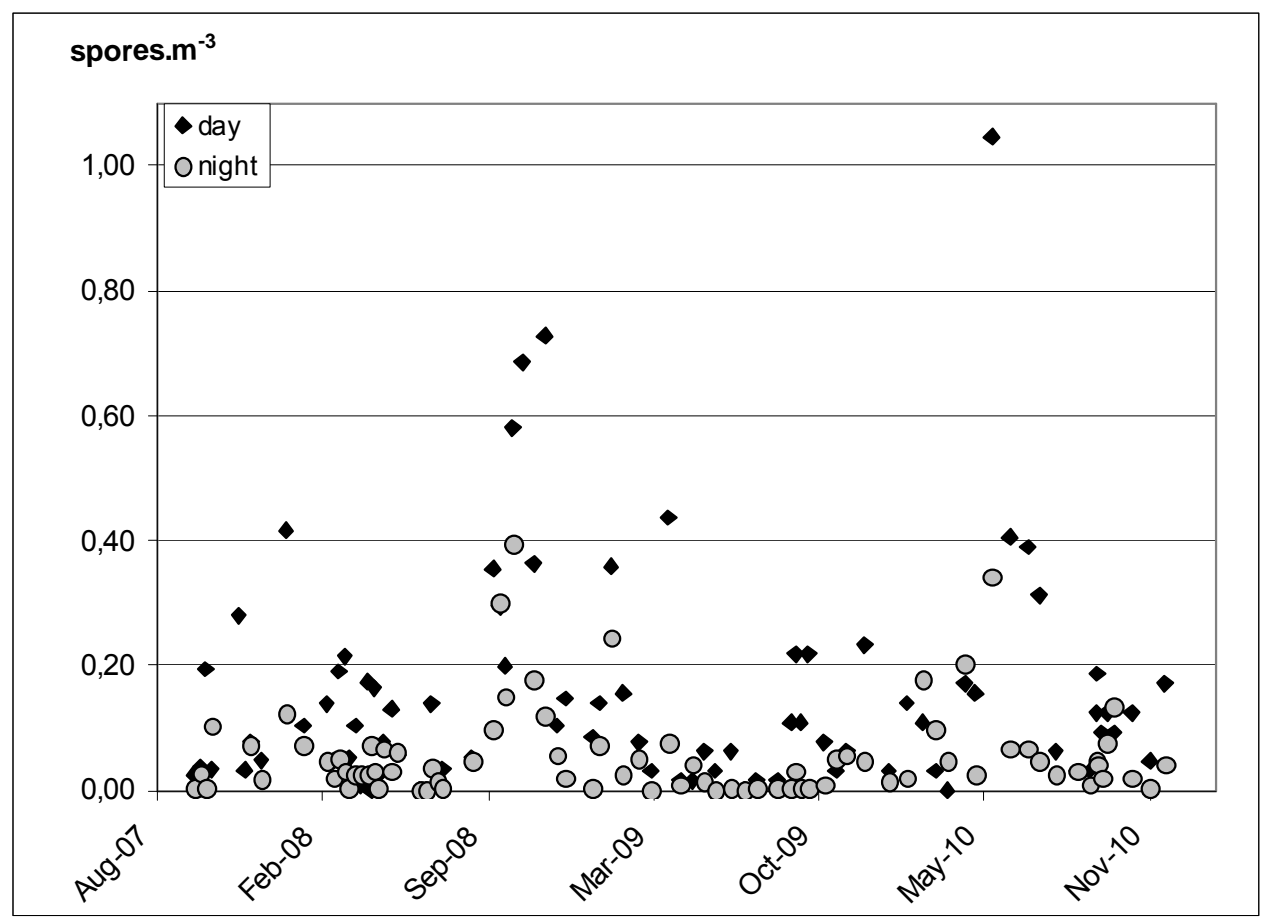

Fig. 2 Diurnal (8:00-17:00) and night (17:00-8:00) concentrations of B. cinerea airborne inoculum during the sampling period (Sept. 2007 to Dec. 2010) 
Version définitive du manuscrit publié dans / Final version of the manuscript published in Aerobiologia, 2013, 29, 2, 291-299. The original publication is available at www.springerlink.com : http://link.springer.com/article/10.1007/s10453-012-9280-0

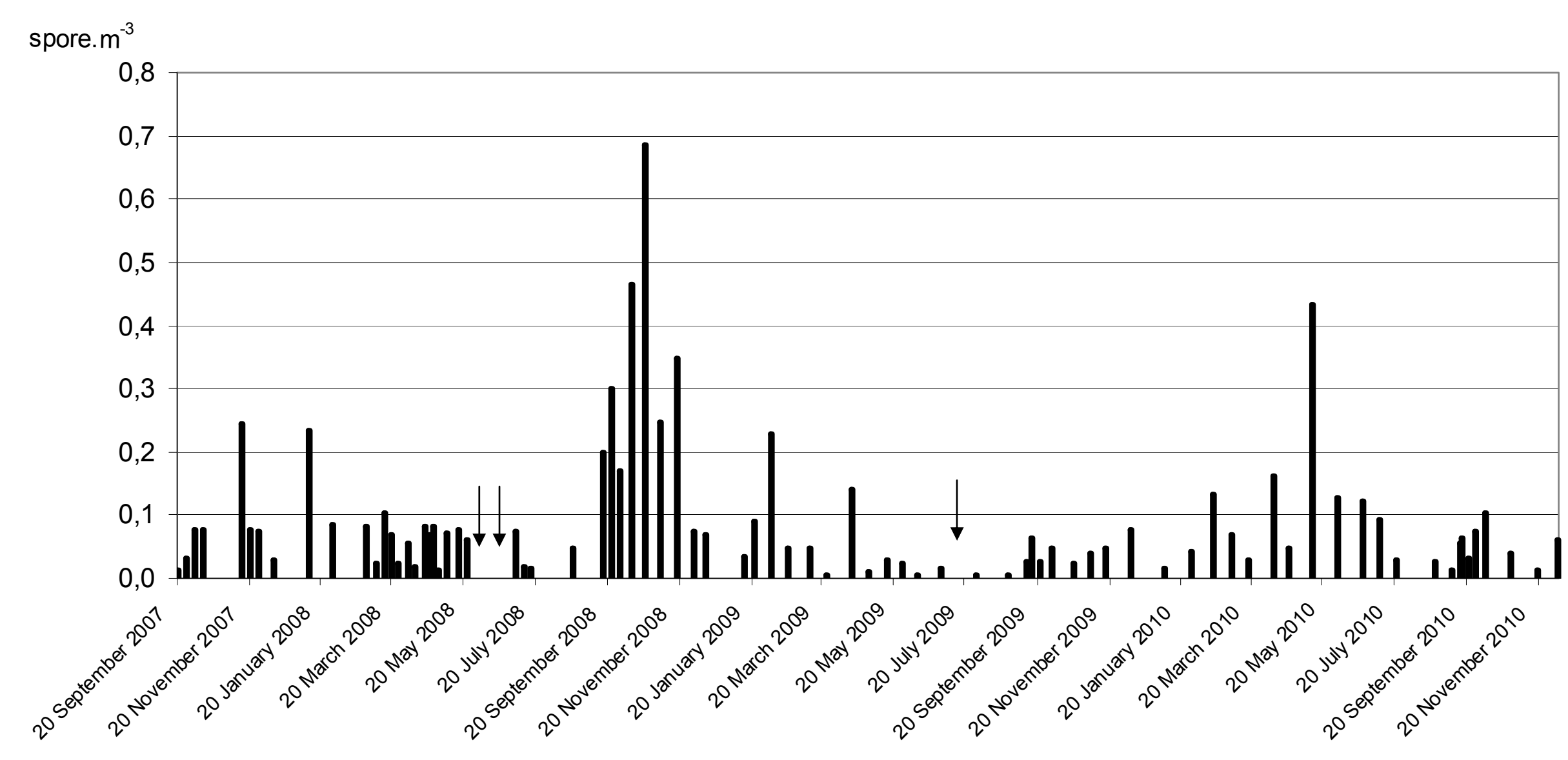

Fig. 3 Daily concentration of Botrytis cinerea during the sampling period (Sept. 2007 to Dec. 2010) representing 84 sampling days. Sampling days with no airborne viable inoculum are marked with arrows (19 and 26 June 2008, 16 July 2009) 
Version définitive du manuscrit publié dans / Final version of the manuscript published in Aerobiologia, 2013, 29, 2, 291-299. The original publication is available at www.springerlink.com : http://link.springer.com/article/10.1007/s10453-012-9280-0

NOAA HYSPLIT MODEL

Backward trajectory ending at 1200 UTC 05 Feb 09

GDAS Meteorological Data
NOAA HYSPLIT MODEL

Backward trajectory ending at 1200 UTC 15 Sep 08

GDAS Meteorological Data
NOAA HYSPLIT MODEL

Backward trajectory ending at 1200 UTC 18 Nov 10 GDAS Meteorological Data

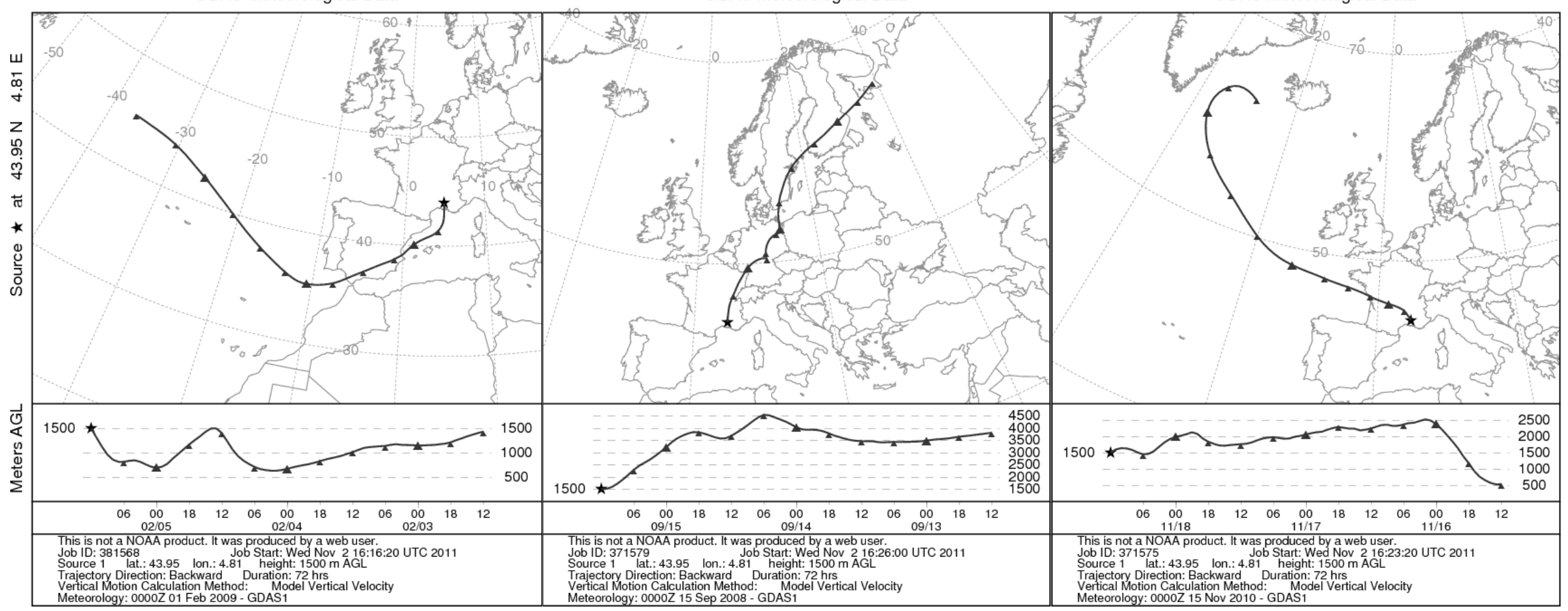

Fig. 4 Typical backward trajectories of air masses arriving in Avignon. From left to right: air masses coming from the South (it spends several hours above the Mediterranean Sea), North (coming from northern Europe and going down to Avignon along the Rhône river valley) and West (it moves above the Atlantic Ocean and then pass above the Central Mountains) 